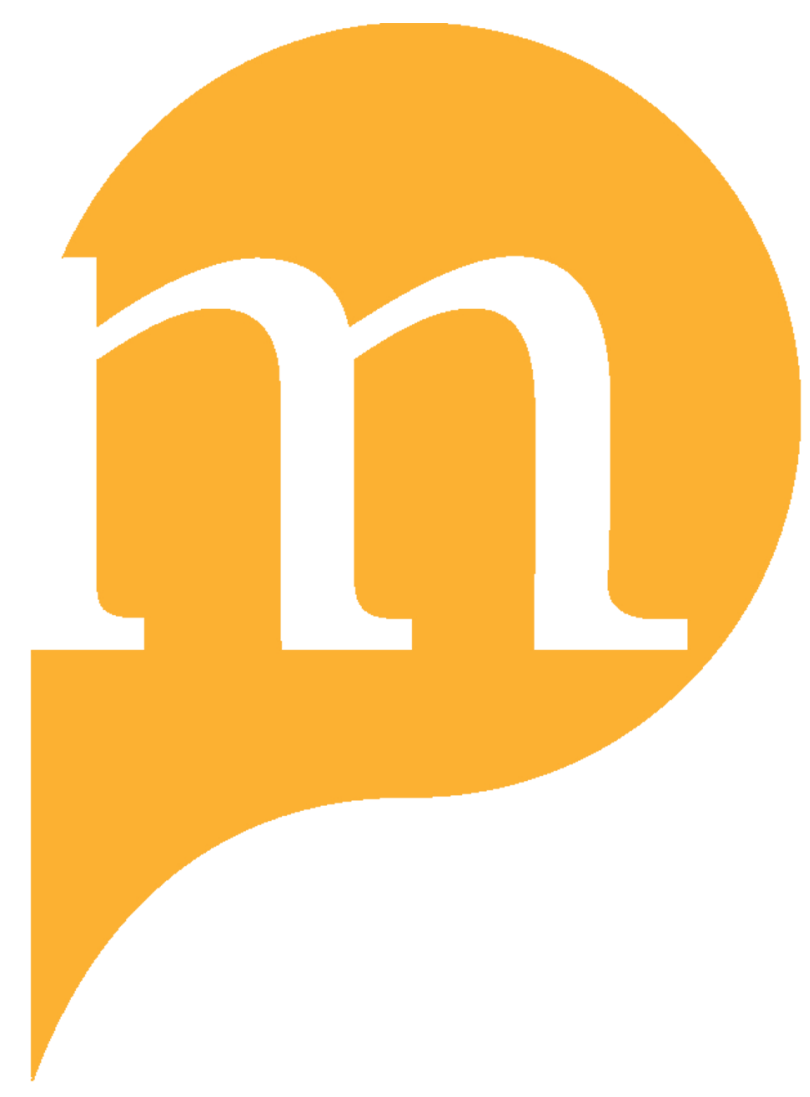

PROJECT MUSE 


\title{
Missing and Misrepresented: Portrayals of Other Ethnic and Racialized Groups in a Greater Toronto Area Ethnocultural Newspaper
}

\begin{abstract}
The vibrant ethnocultural press in the Greater Toronto Area is a testament to the multicultural reality of a metropolitan area where visible minorities are expected to be the majority by 2031 . The GTA's ethnocultural and racialized communities are served by more than 200 newspapers, many of them published in languages other than English or French. What role do these publications play in shaping how ethnic and racialized groups "see" each other? This case study examines how other groups are portrayed in the Chinese-language daily newspaper Ming Pao. With the exception of members of the White community, it concludes that other racial and ethnic groups are represented only to a limited extent and that, in some cases, they are also misrepresented.
\end{abstract}

\section{Résumé}

La presse ethnoculturelle dynamique de la région de Toronto témoigne de la réalité multiculturelle de la zone métropolitaine où on prévoit que les minorités visibles seront majoritaires d'ici 2031. Les communautés ethnoculturelles et racialisées de la région de Toronto ont accès à plus de 200 journaux, dont plusieurs sont publiés dans des langues autres que l'anglais ou le français. Quel est le rôle de ces publications sur leur perception mutuelle les unes des autres? Dans cette étude, nous examinons comment le quotidien Ming Pao de langue chinoise dépeint d'autres groupes ethniques. Nous concluons que, à l'exception de la communauté blanche, les autres groupes ethniques et raciaux y sont peu et même, dans certains cas, faussement représentés.

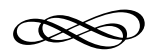

\section{INTRODUCTION}

The vibrant ethnocultural press in the Greater Toronto Area is a testament to the multicultural reality of a metropolitan area that attracted nearly a half million immigrants between 2001 and 2006 (Statistics Canada 2008), and where visible minorities are forecast to be the majority by 2031 (Statistics Canada 2010). Wander into the area's many stores that sell ethnocultural foods and products and you will often see piles of free newspapers published in the language of the store proprietor stacked near the entrance. Stop at a subway newsstand and you can buy local daily newspapers published in Chinese, Korean, Punjabi and other minority languages. 
The debate and discourse appearing in these newspapers and other ethnocultural media have been characterized as overlapping "sphericules" or "smaller loci of social interaction" (Karim 2002, 231) that form the larger public sphere Habermas (1989) envisioned as a space for democratic debate. Scholars have examined various aspects of these sphericules, investigating how ethnocultural news media shape transnational ties and a sense of belonging to more than one locale (Cheng 2005; Lin et al. 2010), their role in forging a sense of local place (Lindgren 2011), and what part they play in helping newcomers adapt and integrate (Ahadi and Murray 2009; BallRokeach et al. 2001; Lin and Song 2006).

Investigations of the norms and standards of journalism practice in ethnocultural media are less common but these issues are beginning to garner attention. Punjabi media in the Greater Toronto Area came under fire recently for taking sides, often against women, in cases of alleged marriage fraud (Aulakh 2011). Members of the Chinese-Canadian community have criticized the quality of journalism aired on Canada's Chinese-language television stations (Yip 2010). And the prominent editor of a Toronto-area Punjabi newspaper told a recent conference examining press freedom in Canada that editors in the ethnic press often choose not to cover sensitive homeland-related issues for fear of retaliation by extremists (Fatima 2012).

This study explores journalism practice as it relates to portrayals of other ethnic and racial groups in ethnocultural media, defined by Matsaganis, Katz and BallRokeach (2011) as news organizations where the content is produced by and for immigrants and racial, ethnic and linguistic minorities. The role of ethnocultural media in shaping minority relations attracted widespread attention in the United States in 2007 when the San Francisco weekly AsianWeek published an inflammatory article entitled "Why I hate blacks" (Citizens Against Racism and Discrimination 2007; Roy 2007). The incident prompted nine major ethnic newspapers and an American ethnic media association to commission a poll of Asian Americans, African Americans, and Hispanic Americans that explored race relations issues. The poll results showed that the majority of African Americans and a significant percentage of Hispanics and Asian Americans viewed news coverage of race-related problems in the ethnic media as irresponsible. The majority of those surveyed, however, also said that ethnic media have an important responsibility when it comes to improving race relations (New America Media 2007).

Closer to home, Canadian scholars have pointed to the need for a better understanding of how ethnocultural news media cover diversity. One investigation of the news published by Vancouver's ethnic media identified a lack of interethnic coverage as problematic. Media and community stakeholders from the local Chinese, Punjabi, Iranian and Korean communities also "expressed some concern with a perceived lack of inter-cultural communication" in interviews with the study's authors 
(Murray et al. 2007, 108). The results prompted speculation about whether Canada "has traded twin solitudes for multiple solitudes" (Murray 2008, 64), and led to calls for "a concerted effort to understand the different news cultures, encourage professional dialogues on news standards in intercultural reporting and recognize excellence" (ibid., 65).

Minelle Mahtani (2008) also eloquently makes the case for more research on representations of other groups in ethnocultural media, arguing that:

The face of the country will continue to change from one that is dominated by a 'white/other' divide to that of an 'other/other' divide, thus making it vital to understand the tensions between racialized groups as well as the tensions between whites and racialized groups. Examining the ways that particular racialized groups understand, perceive and 'make sense' of other racialized groups will be imperative. Thus, research on the particular stereotypes and beliefs racialized groups hold about others and how they are communicated in the ethnic press will prove valuable (247).

This case study answers such calls by examining portrayals of other groups in the local news coverage of Ming Pao, a Toronto-area Chinese-language daily newspaper. The amount of reporting on racial and ethnic groups other than the Chinese community is quantified and the nature of that representation is analyzed.

\section{CONTEXT}

The role of newspapers in providing city residents with information, news and images that allow them to vicariously experience places they may never visit and become acquainted with people they may never personally encounter dates back to the penny press days of the early 1800s (Kaniss 1991; Park 1923). This role is still relevant in that "most members of a community will never know many of their fellow citizens, but come to understand their community, its membership, and its norms through information obtained directly or indirectly via mass media" (Paek et al. $2005,589)$. To the extent that news organizations construct realities, influence beliefs and values, and interpret relationships between places, events and people, they have the power to shape how we "see" the world, including how we imagine groups other than our own (Ibroscheva and Ramaprasad 2008; Lippmann 1997).

Abuses of this power by Canada's mainstream English-language news organizations have been well documented. In the early 1980s, a special parliamentary committee examining the exclusion of visible minorities from much of Canadian society observed that the media "play a powerful role in shaping social values and in developing the esteem which groups in the Canadian mosaic have of each other" (Special Committee on Participation of Visible Minorities in Canadian Society 1984, 94). 
The committee's 1984 final report concluded that the media tended to ignore visible minorities in news coverage, and when they were included, the portrayals were often negative, particularly in foreign and local news items. "A common practice in local reporting is to identify, without any justification, the race of criminals or crime victims if they happen to be visible minorities" (102), committee members noted. The report went on to call for the adoption of standards for reporting on visible minorities, particularly in print media.

In something of a preemptive strike, such standards were included in a major revision of the Canadian Press Stylebook issued a year earlier (Taylor 1983). This style "bible," still widely adhered to by newspapers across the country, outlines common rules on everything from the use of abbreviations to the handling of royal titles. The 1983 edition broke new ground by including a standard that said race, creed, nationality, colour, age or sex should only be identified when the information is relevant to the story. In an article about a racist incident, for instance, identifying the victim's race or ethnicity would be relevant. It would not be appropriate, however, for a story about an armed robbery to mention the racial or ethnic background of an accused under arrest as that detail is not pertinent.

The CP standard attempted to address overt stereotyping, but subsequent studies suggest the problem is far from solved. "The media hold up a mirror in which society can see itself reflected...(but) that mirror's reflections are sometimes severely distorted," Henry and Tator observed in their landmark study of racial bias in Canada's English-language press $(2002,5)$. Other groups still tend to be underrepresented in the White-dominated news coverage of English-language mainstream newspapers and television stations (Diversity Institute 2010). And when members of cultural and ethnic minorities do appear in the news, it is often still in a context that is negative, demonizing and stereotypical (D'Arcy 2007; Henry and Tator 2002; Mahtani 2001). Discourse analysis of the English-language press in Toronto, for instance, found that references to the Vietnamese and Jamaican communities appeared more often in stories and photographs dealing with crime, justice and social problems. The association of these groups with criminal behaviour and other negative stereotypes reinforces readers' perceptions of "us" and "them" and paints "them" as problem people and potential threats (Henry 1999, iii).

Scholars have argued that it is overly simplistic to blame these negative representations of racial and ethnic minorities on deliberate actions by overtly racist journalists in newsrooms across the country. They link the problem to more subtle forms of bias arising from journalistic norms and practices, including news judgments that define bad news as being particularly worthy of coverage. While bad news stories are reported about all people regardless of race or ethnicity, the problem arises when they constitute the only news coverage accorded certain groups (Fleras 2011). More 
generally, journalists also consciously and unconsciously "socially reconstruct reality based on their professional and personal ideologies, corporate interests and cultural and organizational norms and values" (Henry and Tator 2002, 5).

The professional and personal ideologies, corporate interests, and cultural and organizational norms and values of journalists working for ethnic news organizations, however, are not particularly well understood. There is some evidence that the coverage of other racial or ethnic communities in ethnocultural newspapers may be influenced by mainstream news outlets. Research in New Zealand, for instance, identified negative perceptions of Maori among Chinese migrants and linked them to "negative and biased" representations of Maori (Liu 2009, 426) in local Chinese-language media. The study also identified a heavy reliance by Chinese-language news outlets upon translations of stories taken from mainstream news organizations that also underrepresent and misrepresent the Maori community. The researchers concluded that a lack of original reporting, limited resources, and low journalism standards meant Maori were portrayed even more negatively in the Chinese-language media, which focused on the most sensational and negative aspects of Maori-related stories while ignoring more positive coverage.

News coverage of other racial and ethnic groups in ethnocultural media may also be influenced by the attitudes of journalists who immigrate to Canada. Plenty of evidence suggests that negative stereotyping of ethnic and racial minorities in news media is not a uniquely Canadian phenomenon. An examination of representations of otherness in the Russian press, for instance, identified a tendency to highlight fear and anxiety about the rapid growth of the Asian population in the populist newspaper Komsomolskaya Pravda (Davis and Sosnovskaya 2009). A study of news content in Lithuania concluded that anti-Semitism, homophobia and negative portrayals of Roma people featured in that nation's news diet (Tereskinas 2003). Research on how attitudes toward Vietnamese refugees in Hong Kong evolved from humanitarian in the mid-1970s to outright hostility by 1990, suggests that the Hong Kong media typecast the Vietnamese as "deviant, criminous, aggressive and sinister in nature" (Bun 1990, 102). Other investigators, meanwhile, observed that the widespread perception of Vietnamese involvement in crime was exaggerated, not supported by statistics, and resulted at least in part from the fact that "Hong Kong is a relatively over newspapered territory and many crimes that would not warrant press notice elsewhere are well reported and often illustrated" (Hunt 1996, 24).

Finally, the handling of references to other ethnic or racial groups may also be a function of training. The extent to which journalists working for ethnocultural news outlets are aware of best practices related to portrayals of diversity in a multicultural context is unclear. A study of the people who produce ethnocultural publications in Canada found that 41 percent had no business or journalism training (Miller 2006). 
In Vancouver, community and media stakeholders observed that "some people started up media publications as money-making ventures rather than [out of] a desire to present a voice that was not heard" (Murray et al. 2007, 111), and expressed concern about the lack of professional training of journalists and the quality of reporting in non-English media.

\section{METHODOLOGY}

Ming Pao serves the second largest ethnocultural community in the Greater Toronto Area, after South Asians. The GTA's 486,300 residents of Chinese background make up 9.6 percent of the area's population. One fifth of them arrived in Canada between 2001 and 2006 and 74.7 percent were born abroad (Statistics Canada 2006a). The newspaper has a daily circulation of 51,000, a weekly readership of 227,000 and receives 500,000 visits per month to the online website Mingpaoto.ca (Chan 2010).

The Toronto and Vancouver editions of Ming Pao were launched in 1993 and are part of a group of newspapers founded in Hong Kong, where Ming Pao was first published in 1959 (Ming Pao Daily News 2012). At the time of this study, the Toronto-area broadsheet appeared seven days a week and contained approximately eighty pages of editorial content and advertisements. It can be purchased by subscription or from newsstands.

An editorial staff of thirty-five people (fourteen editors, ten reporters, three photographers, five translators, two graphic designers, and one library staff member) was responsible for putting the paper out each day in 2008. Fifteen journalists (two senior editors, nine general news reporters, one local business and finance reporter, and three photographers) handled local GTA content (Lam 2010).

\section{Coding Procedure}

Although Chinese immigrants do not share a single language, most are comfortable reading the single unified written Chinese language in its traditional or simplified version. Two Mandarin-speaking coders who read and write Chinese were responsible for coding Ming Pao, which is published in traditional form. The coders analyzed twenty-eight full issues of Ming Pao published between 7 January 2008 and 23 August 2008. Constructed week sampling (Monday from the first week, Tuesday from the second week, Wednesday from the third week, etcetera) ensured that content from different days was examined and that no major news event was overrepresented.

The coders read each newspaper and identified stories and photographs that dealt primarily with local people, events, issues and places in the Greater Toronto Area. Each local item was then categorized according to one of the general subject categories outlined in Table 1. 
TABLE 1. Subject Categories for Local Articles and Photographs

\begin{tabular}{|c|c|}
\hline PO & Police crime/legal/courts/ocal public safety \\
\hline ED & Education \\
\hline HE & Health/health protection/medical \\
\hline TR & Transit/gridlock'spraw//traffic \\
\hline so & Social supports/affordable housing/poverty/social justice \\
\hline LU & Land use/urban design/developmentredevelopment \\
\hline MU & Municipal politics/services/budget \\
\hline EW & Environmentweather \\
\hline FA & Fire/accident \\
\hline RI & Religious-cultural diversity/multiculturalism/immigration \\
\hline $\mathrm{AE}$ & Arts/entertainment/local attractions \\
\hline BU & Business \\
\hline SP & Sports \\
\hline NS & Local impact of national security terrorism/foreign policy/foreign disasters/human rights Canadian soldiers/casualties \\
\hline FP & Federal or provincial politics initiatives - local angle \\
\hline OT & Other pets travel human interest \\
\hline
\end{tabular}

Other information collected for each news item included its location in the newspaper, whether it was produced by a staff reporter or taken from a newswire service, and identification of the news item's form (news story, photograph, column, editorial, review, letter, or item submitted by readers). Where a particular ethnic or racial group was referenced in a local story, or where people of an identifiable racial or ethnic background appeared in a local photograph, this information was added to the database. Although ethnicity is often used to refer to cultural practices and race refers to physical attributes (Pyke and Dang 2003), both terms are used in this study because news stories contained both types of references.

Where there was no reference to race or ethnicity in a story, the story was classified as referring to the "general community." If a story referenced the Black community, the Indian community, and the Chinese community, coders entered each of those references into the database. Coding options also included more general descriptors such as Asian, South Asian, and Southeast Asian because some stories used these references and, in some photographs, it was impossible to be more specific about subjects' backgrounds.

In the case of photographs, coders used information from accompanying stories, photo information lines (cut lines) and visual inspections to decide the racial or ethnic background of subjects. Where there was the slightest uncertainty as to an individual's background, coders entered "not identifiable" into the database. A photo featuring a White person, a Black person and a person or persons of unidentifiable background, for instance, would merit three entries in the database: White, Black, and Unidentifiable.

Following coder training, a full intercoder reliability test was conducted based on the standards and guidelines outlined by Lombard, Snyder-Duch, and Bracken 
(2002). Intercoder reliability for interval variables, such as the number of local articles and photographs, was calculated using Lin's Concordance. Reliability for two coders was considered acceptable at or above .700. Across five test issues, the Lin's Concordance coefficient was at or above .716 for all item count variables, with the exception of ten minor variables. In most of these cases, the low level of agreement was due to the small number of news items in the category. These variables were eliminated from the analysis and discussion.

Intercoder reliability for nominal variables, such as the subject matter of each news item, was measured using Cohen's Kappa, a relatively conservative index (Lombard et al. 2002). Reliability was considered acceptable at or above .700. At the item level, intercoder reliability was at or above .754 for all variables with one exception. This variable was eliminated from the analysis and discussion.

Prior to incorporating the test issues into the full twenty-eight-issue sample, disagreements that surfaced during the intercoder reliability test were resolved through discussion and, where necessary, clarification of the coding guide.

\section{Assessing Diversity Representation}

Representations of diversity were examined in three ways. Data were analyzed to see how many different racial and ethnic groups other than Chinese were referenced in Ming Pao and how often they showed up in stories and photographs. Stories and photos that contained references to other groups were then examined in terms of their subject matter to explore how the groups were portrayed. Finally, all the local news items that referenced groups other than Chinese were examined for consistency with the CP standard for when to mention race or ethnicity (Tasko 2006). Coders translated the headlines, provided a short English summary of the article or photograph cutline, and translated the key sentences that referenced race or ethnicity. The news item was then categorized as consistent or inconsistent with CP style.

References to the Chinese community were not tested for consistency with the $\mathrm{CP}$ standard because it is reasonable to expect a news organization that targets the Chinese community to highlight its members' involvement in activities, tragedies, crime, and successes. Explicitly mentioning the involvement of Chinese community members in news items, in other words, is a key part of Ming Pao's raison d'être. The newspaper, for example, published a story about a van hitting an elderly woman and identified the pedestrian as being of Chinese origin. Strict adherence to the CP standard would mean the victim's background would not be reported. It seemed unreasonable, however, to critique the newspaper's handling of the issue in this case since the fact that the victim was Chinese was the reason for publishing the story. 


\section{RESULTS}

\section{Breakdown of Local News by Subject}

News related to police and crime was the number one local topic in Ming Pao, accounting for 209 photographs and stories or 18 percent of all local news items (Figure 1). The next most common news category dealt with religious, cultural, and immigration matters. Within this category, the dominant subtopic was news about community festivals and celebrations. Business news ranked third among the main categories, followed by arts and entertainment-related coverage.

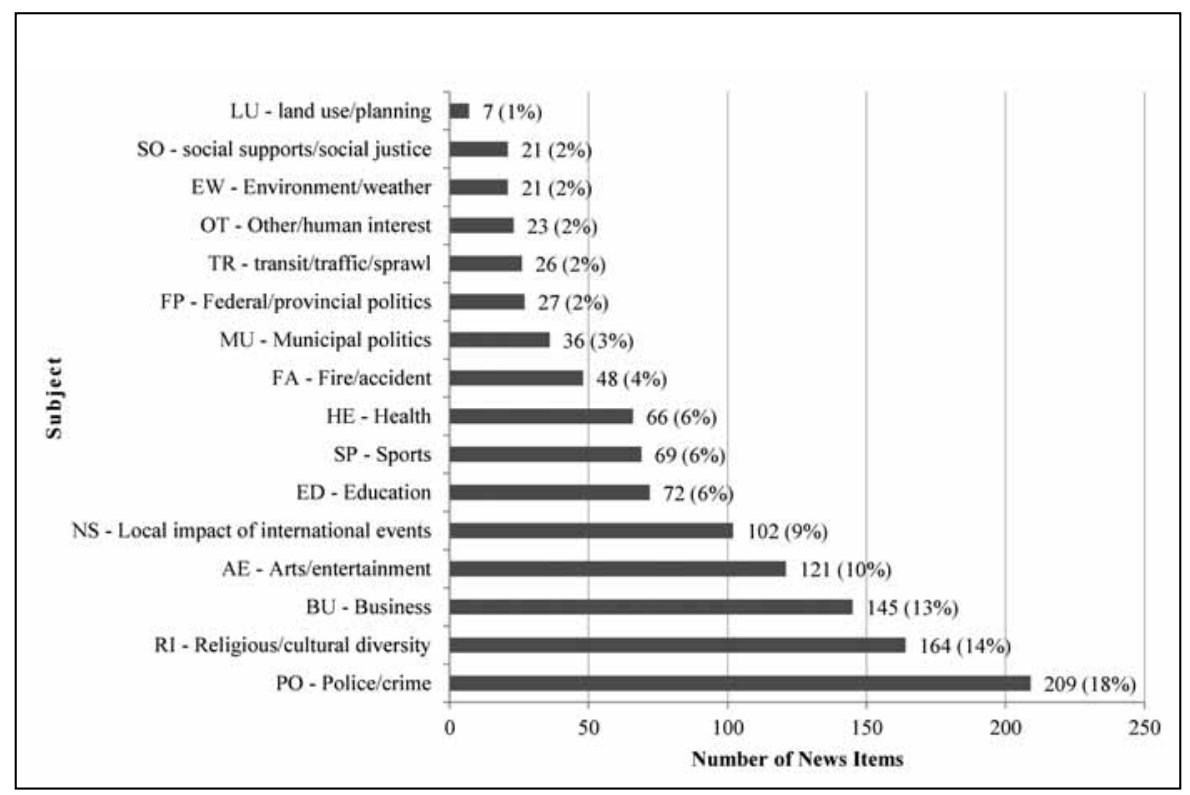

Fig. 1. Local News in Ming Pao: Breakdown by Subject

\section{Number of References to Different Groups}

Of the 1,157 local news items (photographs and stories) published in the paper, nearly half (544) did not reference a racialized or ethnic group or were photographs where coders could not identify the racial or ethnic background of the subjects (Figure 2). A total of 613 news items did reference a racialized or ethnic group. Of these, 329 local news items (28\% of all local news items) referenced the Chinese community exclusively. Other racialized and ethnic groups were represented in 284 news items (230 photographs and 54 stories), including ninety items that contained references to the Chinese community plus one or more other racialized or ethnic group. 


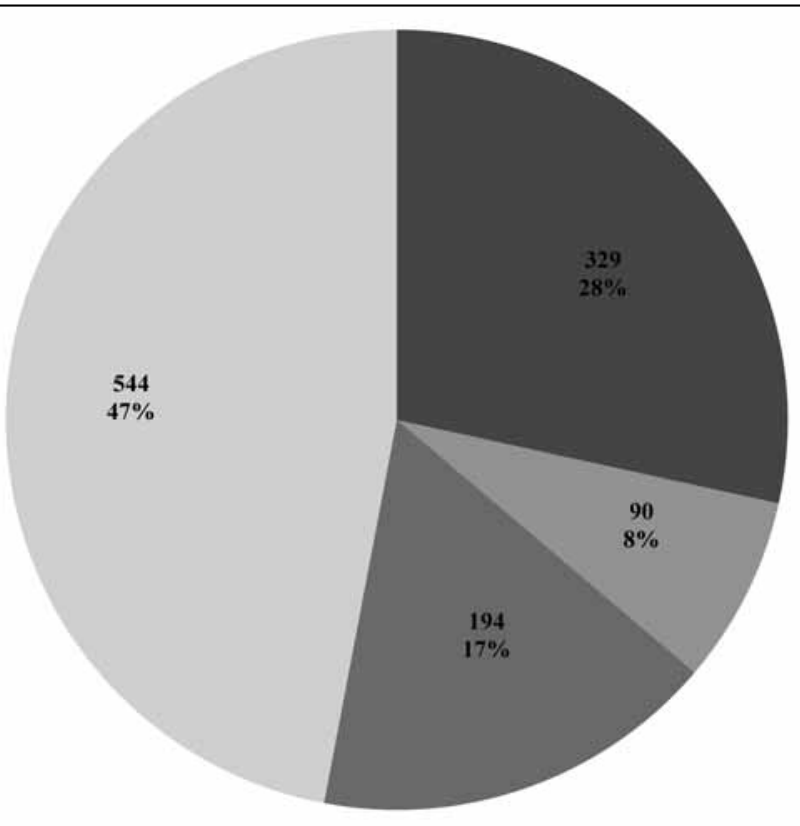

- Items with Chinese references only

= Items with Chinese plus references to other racial/ethnic group

- Items with racial/ethnic references other than Chinese

w Items with no identifiable group or no reference to racial/ethnic groups

Fig. 2. Breakdown of 1,157 Local News Items by References to Racialized/Ethnic Groups

Overall, the data indicate that approximately 25 percent of all local news items published in Ming Pao referenced groups other than Chinese. An in-depth examination of the news items that contained racial or ethnic group references, however, revealed that the diversity representation was more limited than it appears at first glance (Table 2). The detailed analysis identified a total of 793 references to racial or ethnic groups (some of the 613 individual news items referenced more than one group), including 419 references to the Chinese community.

Among the remaining 374 non-Chinese references, the White community appeared most frequently (173 times exclusively in photographs). Members of the Black community were referenced in both photographs and stories, but this happened much less frequently than for the Chinese or White communities. After that, references to other groups dropped precipitously so that, although twenty-two racialized or ethnic groups other than Chinese showed up in the newspaper, half of those groups made only a single appearance. 
TABLE 2. References to Race/Ethnicity in Ming Pao

\begin{tabular}{|c|c|c|c|}
\hline & In Photos & In News/Feature Stories & $\begin{array}{c}\text { Total } \\
\text { References }\end{array}$ \\
\hline Chinese (all references) & 186 & 233 & 419 \\
\hline White & 173 & & 173 \\
\hline Not Identifiable ' & 69 & & 69 \\
\hline Black community & 34 & 11 & 45 \\
\hline $\begin{array}{l}\text { Asian (Asian, East Asian, South Asian or } \\
\text { Southeast Asian)? }\end{array}$ & 14 & 6 & 20 \\
\hline Multiple ethnic groups (general reference) ${ }^{3}$ & & 17 & 17 \\
\hline Victnam & 1 & 8 & 9 \\
\hline Korea & 2 & 6 & 8 \\
\hline India & & 5 & 5 \\
\hline Italian & 1 & 3 & 4 \\
\hline Caribbean community & 3 & 1 & 4 \\
\hline Philippines & & 4 & 4 \\
\hline Japanese & & 3 & 3 \\
\hline $\begin{array}{l}\text { South Asian (India, Pakistan, Bangladesh, Afghanistan, } \\
\text { Iran, Sri Lanka, Nepal) }{ }^{2}\end{array}$ & & 2 & 2 \\
\hline Bangladesh & & 1 & 1 \\
\hline Burma (Myanmar) & & 1 & 1 \\
\hline Cambodia & & 1 & 1 \\
\hline $\begin{array}{l}\text { East Asian (China, Japan, } \\
\text { Korea, Taiwan) }{ }^{2}\end{array}$ & 1 & & 1 \\
\hline France & & 1 & 1 \\
\hline Indonesia & & 1 & 1 \\
\hline Israeli & & 1 & 1 \\
\hline Jamaican community & & 1 & 1 \\
\hline Pakistan & 1 & & 1 \\
\hline $\begin{array}{l}\text { Southeast Asia (Philippines, Thailand, Vietnam, Singapore, } \\
\text { Cambodia, Brunei, Indonesia, Laos, Myanmar, East Timor) }{ }^{2}\end{array}$ & & 1 & 1 \\
\hline Taiwan & & 1 & 1 \\
\hline Total & 485 & 308 & $793^{4}$ \\
\hline
\end{tabular}

' Used where race/ethnicity was not identified in relation to photograph

2General references to Asian, East Asian, South Asian or Southeast Asian in news stories or photos of people of Asian, East Asian,

South Asian or Southeast Asian background where specific information is lacking .

"General references to ethnic groups where no specific groups were identifiod e.g. references to "ethnic" communities or "immigrants"

${ }^{4}$ Total number of race/ethnicity references in 613 local news items that mention race/ethnicity

\section{Subject Matter of News Items Referencing Other Groups}

The next step in the analysis involved investigating the type of news coverage accorded different groups. The Chinese community, included here for comparison purposes, tended to be cast in a generally positive light, appearing most often in photographs (Figure 3) and stories (Figure 4) in the RI category (religious/cultural diversity, multiculturalism, and immigration issues), a category dominated by news coverage of community festivals and celebrations. The next most common subject for news items referencing the Chinese community was the NS category (local aspects of foreign disasters and other international events), which, for the most part, told the positive story of the local Chinese community's fundraising and other efforts to help in the aftermath of the 2008 Szechuan earthquake. While the third most common topic was the PO category (police and crime-related items), this less positive coverage accounted for just 13 percent or fifty-four stories and photographs out of 419 news items that included references to the Chinese community.

Members of the White community turned up most often in police and crimerelated photographs (Figure 3), but this category still only accounted for 18 percent or thirty-one of the 173 photos. A detailed examination of the photos in this category 


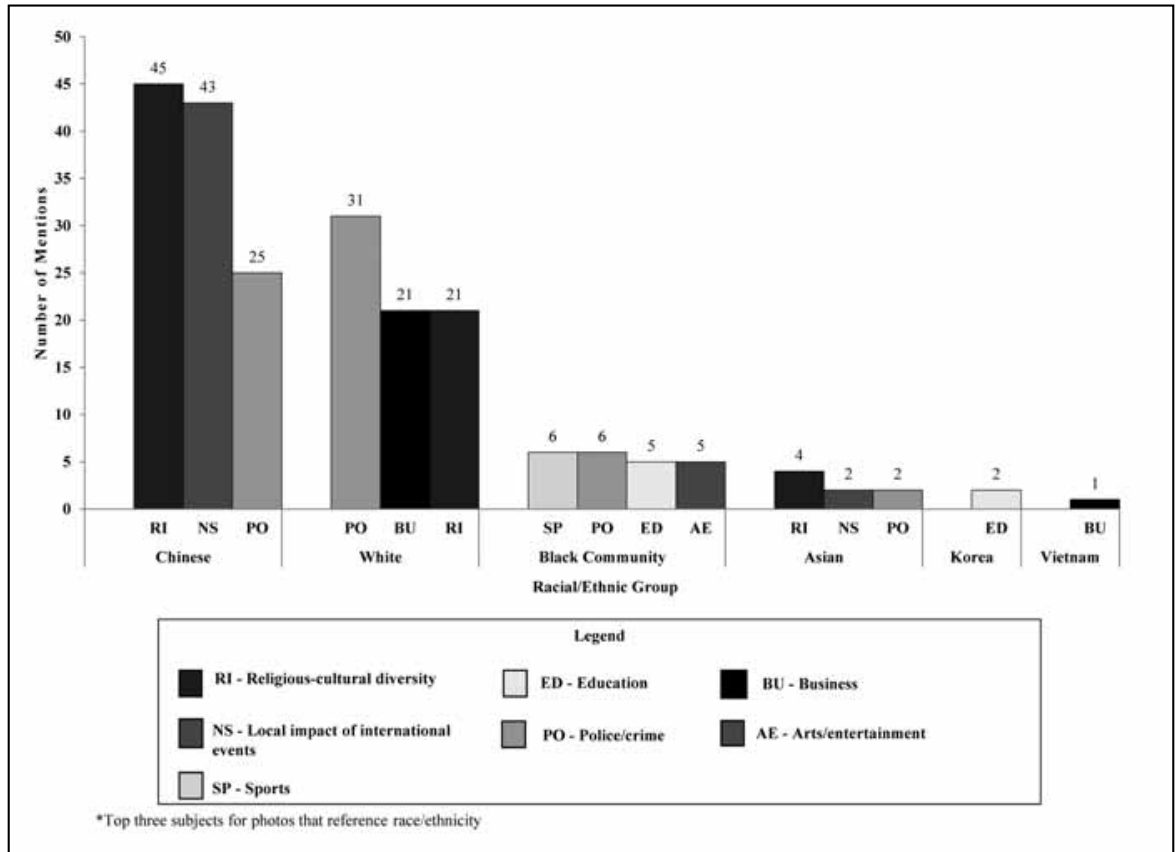

Fig. 3. Ming Pao Photos Referencing Race/Ethnicity by Subject*

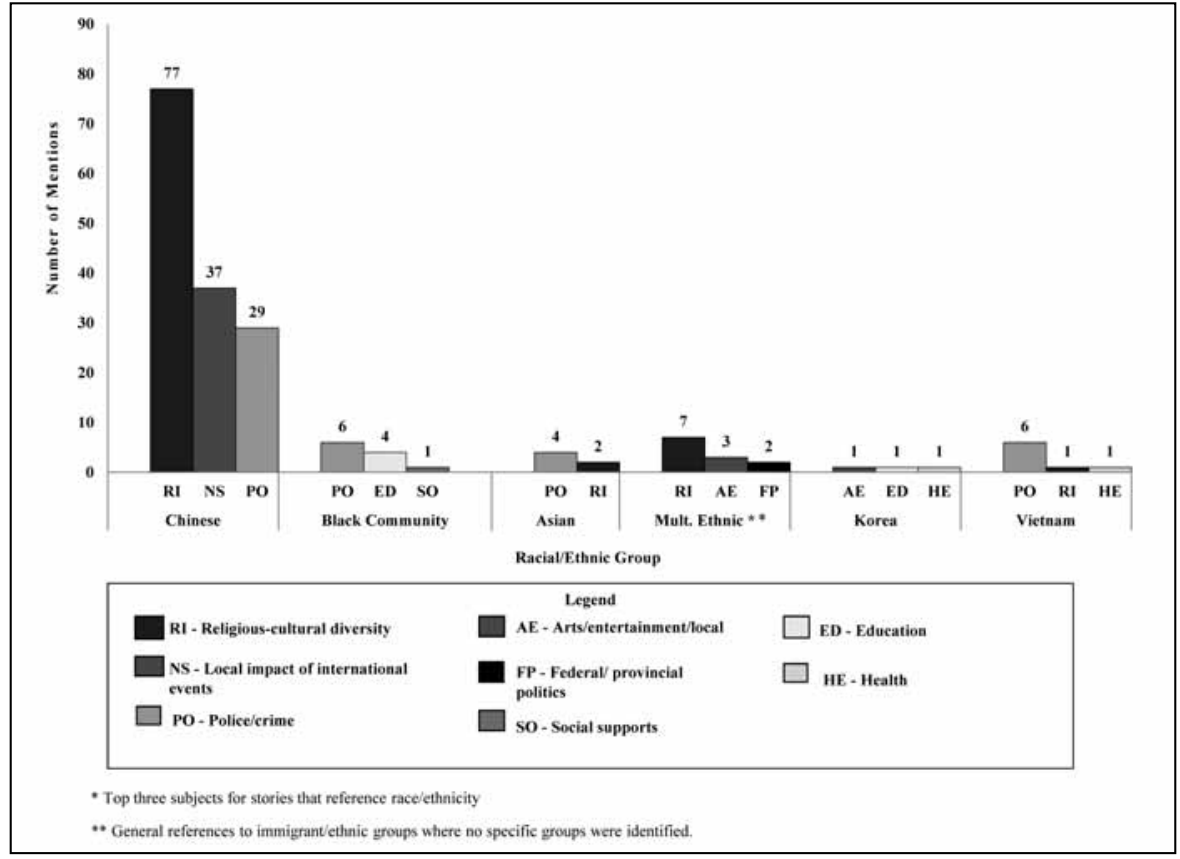

Fig. 4. Ming Pao Stories Referencing Race/Ethnicity by Subject* 
also revealed that portrayals of White community members in a crime-related context were often actually positive. In seventeen of the thirty-one police and crimerelated images, the White individuals were police officers, lawyers acting on behalf of accused clients, or other authority figures.

News items about groups other than the Chinese or White communities tended to be less flattering. In particular, police and crime-related stories dominated news coverage that referenced the Vietnamese community and, to a lesser extent, the Black community (Figure 4). Overall, 66 percent or six of the nine news items (photo and stories) referencing the Vietnamese community were police or crime-related stories that portrayed the group in a negative light. Five of the stories dealt with drug crimes and the sixth was an account of two women fighting over a parking space.

While the problem was less pronounced, coverage of the Black community also tended to be weighted toward police and crime coverage: 26 percent or twelve of the forty-five photographs and stories that mentioned the group dealt with aspects of police or crime-related issues, including six items that dealt specifically with murder and other violent crime. The next most common topic was education, accounting for nine news items or 20 percent of all coverage referencing the Black community.

\section{Compliance with Canadian Press Standards}

All 284 news items that referenced non-Chinese groups were examined for consistency with the Canadian Press standard for mentions of race or ethnicity. Translations of the cutlines accompanying the 230 photographs resulted in the identification of three CP-inconsistent cases including:

- A photograph of two schoolgirls published with a cutline that said: "Tiffany and her Korean classmate, Sue, students of Silverstream Elementary School, designed a water vacuum" (Ming Pao 2008c).

- A photograph of three people published with a cutline that said: "Three members of the Black community celebrate the development of Caribana" (Ming Pao 2008d).

- A photograph of a woman published with a cutline that said: "Vietnamese female factory worker, Miss Liao, couldn't help crying when talking about the future" (Ming Pao 2008g).

All three examples violate the CP standard in that there is no reason to identify individuals in the photos by their racial or ethnic background. It was not pertinent that the schoolgirl was Korean, the Caribana organizers were Black, or that the factory worker was Vietnamese.

A detailed reading and translation of the fifty-four news stories that referenced non-Chinese racial or ethnic groups identified thirteen stories, or 24 percent of the 
total, that did not conform to the CP standard. Examples of stories where there was no valid reason for mentioning the race or ethnicity of individuals included:

- A story that described an armed robbery with repeated references to "two Black men" as the perpetrators (Ming Pao 2008a).

- A story that began by saying, "Last night in Scarborough's Markham Road and Lawrence area, a young Black man sitting in his SUV was hit by a bullet to the chest" (Ming Pao 2008b).

- A story that ran under the headline "Vietnamese man charged, involved in three marijuana grow-ops in Markham" (Ming Pao 2008e) and included repeated references in the body of the article to a Vietnamese man as the accused.

- A story with the headline "Tragedy strikes Brampton: mentally ill man harms own child with knife" (Ming Pao 2008f) that began by saying, "In the South Asian residential area of Brampton, a horrifying event happened when a father, possibly with mental illness, harmed his eleven-year-old son." In this case, the decision to describe the neighbourhood as South Asian is questionable not only in terms of relevancy but in terms of accuracy: it is not at all clear that the individuals involved were South Asian.

The Vietnamese community was the group most often portrayed in a way that was inconsistent with the CP standard (Figure 5). It was referenced a total of nine times (in one photo and eight stories) during the period studied; seven of those references (one photo and six stories) violated the CP standard. The Black community was referenced in a way that did not comply with the CP standard in four of the eleven stories that mentioned the community as well as in one of thirty-four photos.

Additional analysis showed that violations of CP standards occurred most frequently in news items dealing with police or crime-related issues (Figure 6) and that the Vietnamese community was the group most often inappropriately mentioned in these stories (Figure 7). To put this in perspective, six of the eight stories that mentioned the Vietnamese community were police-related and, in all six cases, the references violated the CP standard.

The problem was less pronounced, but still something of an issue in the newspaper's police and crime coverage involving members of the Black community. While the CP standard was observed for police-related photographs, three of the six police and crime-related stories that referenced the Black community did so in a way that was inconsistent with the CP standard. 


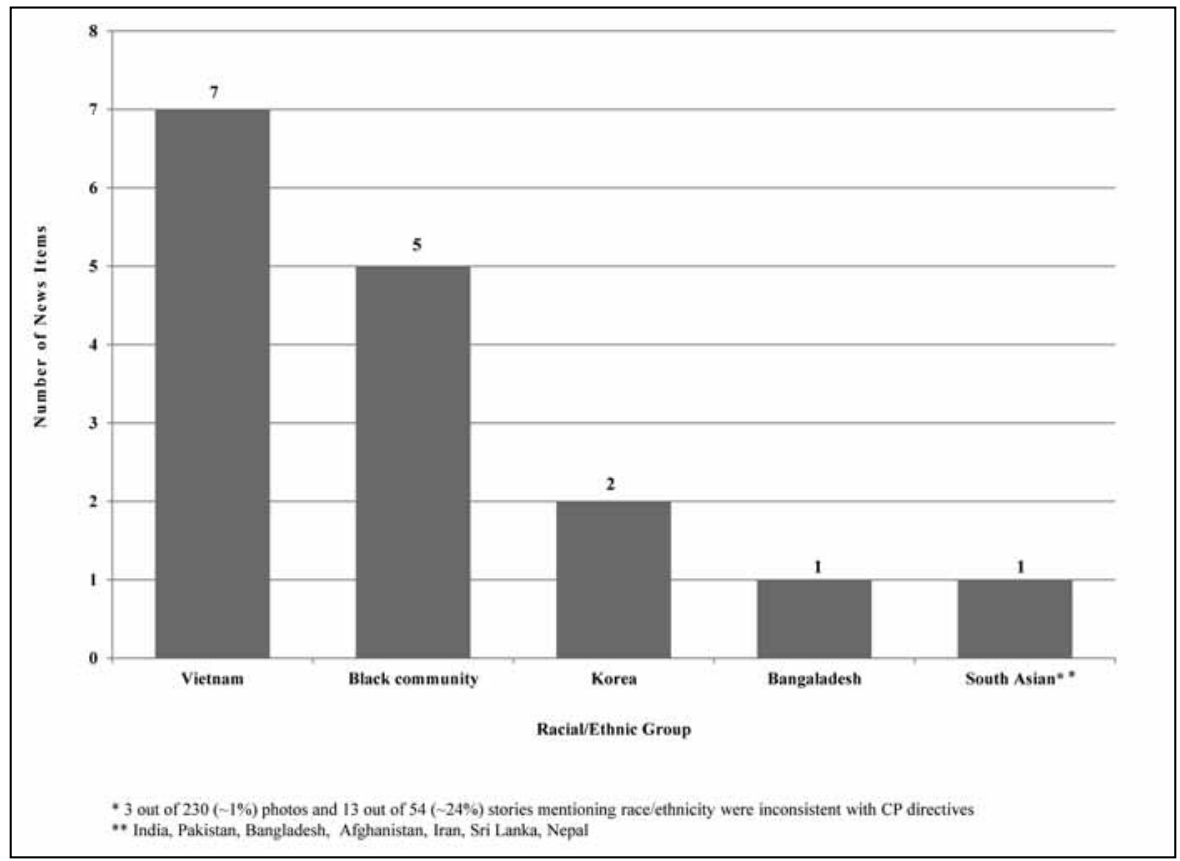

Fig. 5. Number of News Items that Mention Race/Ethnicity in a Way that is Inconsistent with CP Style*

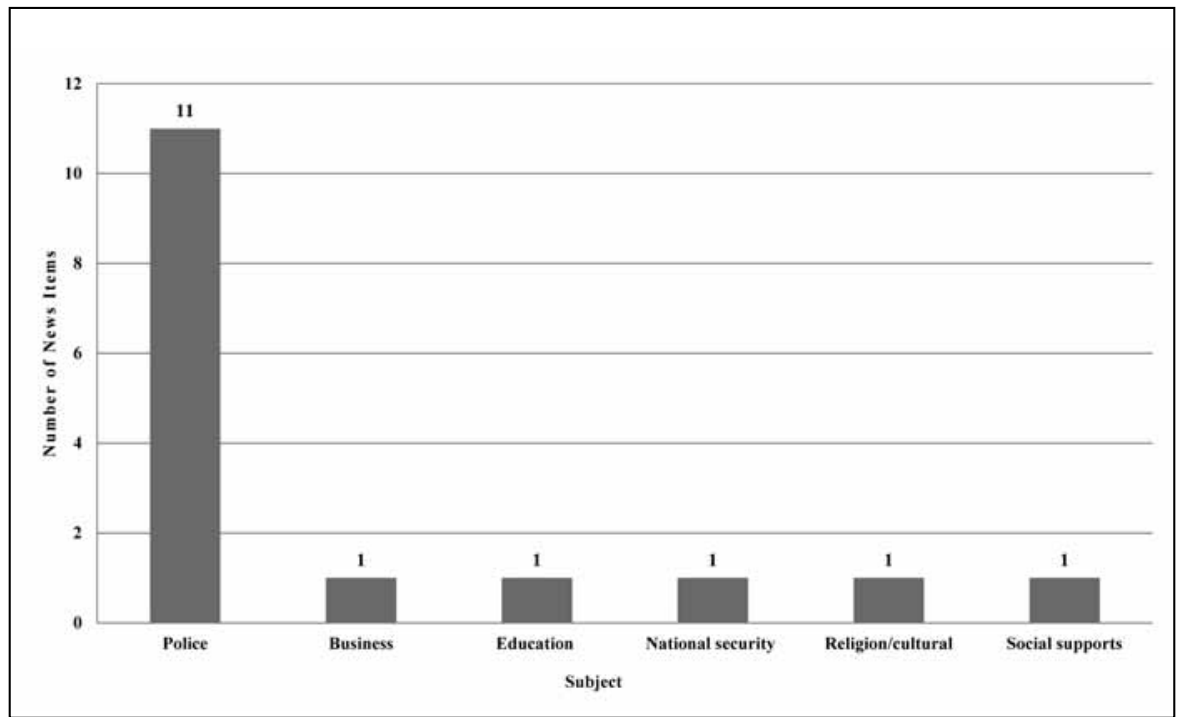

Fig. 6. Most Violations of CP Standards on Race/Ethnicity Occurred in Police-related News 


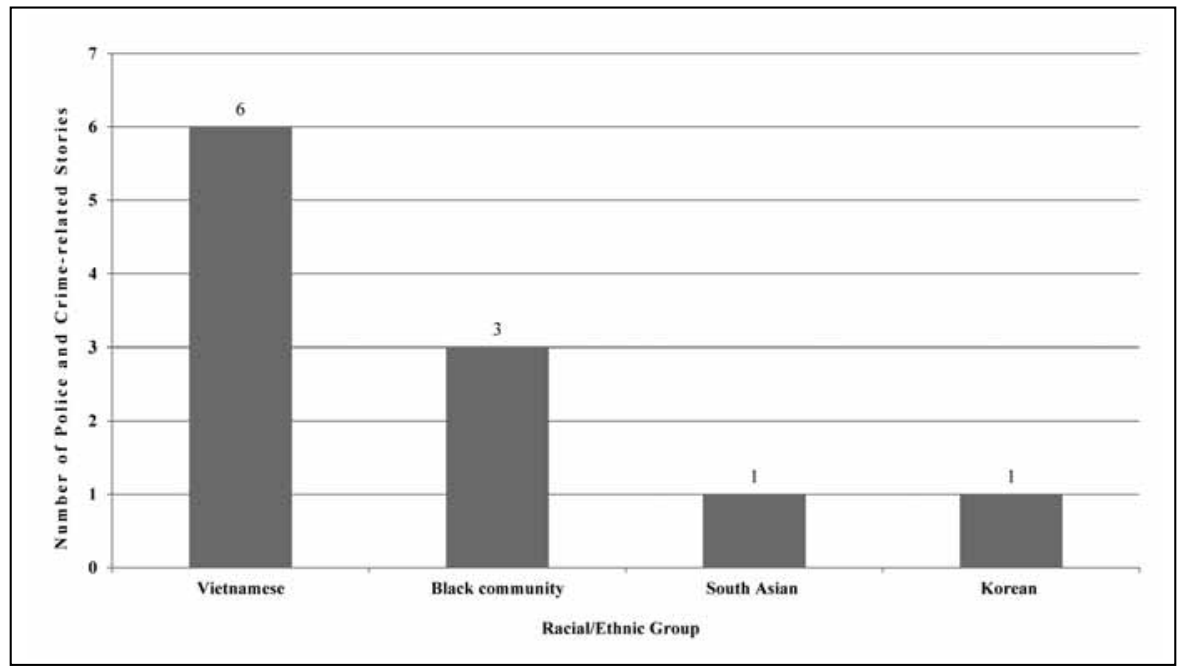

Fig. 7. Members of the Vietnamese Community were Most Frequently Mentioned in Police and Crime-related Stories in a Way that was Inconsistent with CP Standards

\section{DisCUSSION}

Residents of the GTA have access to a rich offering of English-language media, but many members of minority language communities still turn to the region's 200 free ethnocultural publications (DiversiPro 2007) and ten daily newspapers (Diversity Institute 2010) for news and information. In some cases, this is a necessity. Nearly 19 percent or 77,000 of the 410,865 residents in the Greater Toronto Area with a Chinese-language mother tongue speak neither English nor French (Statistics Canada 2006b). The appeal of ethnocultural media, however, extends beyond residents who can't speak either of Canada's official languages. A survey of 3,000 new Canadians in Toronto, Vancouver, and Montreal found that Chinese-Canadians in particular were heavy consumers of news media in their own language, with 75 percent turning to at least one ethnic newspaper, radio or television station in the previous seven days (Solutions Research Group 2006). The same study reported that English-language newspapers reached only 50 percent of Chinese-Canadians. This result is consistent with a subsequent survey of first-generation Chinese-Canadians in the Greater Toronto Area and the Greater Vancouver Area where 52 percent of respondents said they read Chinese-language magazines and newspapers exclusively (Ipsos Reid 2007).

Accessing news in a familiar language offers a break from the demands of working and living in English. But ethnocultural media also play a role in combating negative stereotypes, celebrating accomplishments, and providing information not 
available to ethnic communities that are underrepresented in mainstream media (Fleras 2009). Ming Pao, for instance, published 329 stories and photos that referenced the Chinese community exclusively (there were no references to other racial or ethnic groups in the same item) during the twenty-eight days examined for this study. The comparable figure for the Toronto Star on exactly the same days was twenty-one.

Since Ming Pao's raison d'être is to tell stories about the Chinese community to the Chinese community, does it need to reflect the diversity of the GTA's population? The editors and publishers of ethnocultural publications themselves suggest the answer to this question is "yes." In an interview with the author, Tak Yin Lam, deputy editor-in-chief of Ming Pao's Toronto edition, said that providing readers with information that helps them understand Canada is one of his priorities (Lam 2010). More generally, 45 percent of ethnic newspaper editors and publishers said in a Canadawide survey that their publications serve readers by building bridges between cultures (Miller 2006). In practical terms, Ming Pao and other ethnocultural publications offer insights and introductions to "unlike" people by including them in stories and photographs. In doing so, journalists lay the foundations for bridgebuilding, foster intercultural understanding, and help readers understand the diversity that is a defining characteristic of the Greater Toronto Area.

Fleras makes the important point that ethnocultural media can play a dual role, acting as both "instruments of cultural preservation as well as agents of societal incorporation" (2009, 727). Research by Putnam (2007), he notes, suggests that trust and residents' openness to connecting with others declines, at least in the short term, as communities become more diverse. This, in turn, increases the pressure on ethnocultural media to "neutralize this disconnection and distrust, in part by providing both the bridging capital between different groups (ties to people unlike you), in part by securing bonding capital within one's own group (ties to people like you)" $(2009,727)$. By publishing photos of the White community, for instance, Ming Pao is "introducing" readers to the largest racial group in the GTA, ensuring that they will figure in readers' imagined communities as police officers, politicians, lawyers, teachers and in numerous other roles. These introductions, however, occurred much less frequently for other groups. The near invisibility of these other groups raises questions about the newspaper's bridge-building role and the extent to which it is fulfilling its goal of equipping readers with the information they need to understand the place where they live.

The data also pointed to problems with the type of news coverage accorded the Vietnamese community and, to a lesser extent, the Black community. The newspaper's preoccupation with police and crime coverage indicates that journalists at the newspaper, like their mainstream counterparts, consider bad news a staple. The focus on 
police and crime reporting, however, also sets the stage for problematic portrayals of some groups when this negative coverage is not offset by other types of stories.

Crime- and police-related news, for instance, accounted for just 13 percent of Ming Pao's coverage of the Chinese community, and 18 percent of reporting on the GTA's majority (at least for the time being) White community. By comparison, coverage of the Vietnamese and Black communities was less extensive, less varied and, as a result, less positive overall: 66 percent of news items referencing the Vietnamese community and 26 percent of news items referencing the Black community focused on police and crime-related news. In the case of coverage of the Black community, the proportion of photos and stories with negative connotations actually rose to 33 percent when items about a Black baby girl abandoned in a parking garage stairwell were taken into consideration. These items were coded under the social services category which encompassed child welfare issues.

Negative typecasting of the Vietnamese community in particular was further reinforced by news reporting inconsistent with the Canadian Press standard for when mentions of race and ethnicity are justified. The fact that the problem was most pronounced in police and crime-related stories is eerily reminiscent of the findings of the Equality Now report, where parliamentarians pointed to local crime news as particularly problematic when it came to the unjustified identification of criminals or crime victims by race or ethnicity (Special Committee on Participation of Visible Minorities in Canadian Society 1984).

Possible explanations for the underrepresentation and misrepresentation of other racialized and ethnic groups in Ming Pao come together in a tangled web. There is evidence, for instance, that mainstream news coverage also portrays the Vietnamese community and Black members of the Jamaican community as problematic (Henry and Tator 2002). So to the extent that Ming Pao's editors and reporters are influenced by the English-language media's news agendas and framing of stories, it is possible that these biases seeped across the language barrier.

The values and journalism norms of Ming Pao editors and reporters themselves, however, cannot be ruled out as factors that also contributed to the lack of representation or misrepresentation of other groups in the newspaper. Most Ming Pao staff, for instance, were born and trained in China (Lam 2010), so they may have brought with them the attitudes and professional practices that resulted in the Hong Kong media's strikingly negative portrayals of the Vietnamese community (Bun 1990; Hunt 1996). Another possibility is that, as members of a racialized minority occupying less powerful positions in a White-dominated society, a certain amount of scapegoating is happening (Agroskin and Jonas 2010; Cheng and Espiritu 1989) where the journalists at Ming Pao "themselves work to reproduce the dominant system by distancing themselves from Others...." (Jiwani 2006, 58). 
Finally, lack of familiarity with issues associated with racial or ethnic stereotyping and Canadian journalism practice, including Canadian Press style and standards, may also contribute to the underrepresentation and misrepresentation of other groups. The training of reporters who work in ethnic media has surfaced repeatedly over the years as an issue in scholarly research (Husband 2005; Murray et al. 2007; Miller 2006). And a recent survey of Canadian ethnic media concluded that there remains "an absence of support, direction and mechanism for continuous professional development and improvement" (Huston 2012, 13). At Ming Pao, the China and Hong Kong-based training of the majority of reporters and editors may mean that they are unaware of the $\mathrm{CP}$ standard and other Canadian norms associated with covering diverse communities.

Analyses of the Ming Pao data provide no direct evidence for scapegoating, imported prejudices, bias "seepage" or lack of training related to representations of diversity. But the data do suggest that the newspaper's editorial staff produces news that is much more than a translated version of stories published by mainstream English-language media. Of the 284 news photographs and stories referencing other racial or ethnic groups, for instance, 74 percent were produced by Ming Pao staff or were obtained by Ming Pao staff from the public (community-supplied photos, for instance). The preponderance of coverage produced in-house suggests that the newspaper's editors and reporters exercised considerable control over what stories they chose to cover, how they covered them, and how other racialized or ethnic groups were portrayed.

This study found that the images constructed of different racial and ethnic groups in locally generated coverage varied depending on the group. Nearly three-quarters (71\%) of the 173 photographs of the White community were taken by staff photographers or sought out by the paper and, overall, depictions of this group were generally positive. The breakdown of topics for photos and stories (Figures 3 and 4) indicates that most other racial or ethnic groups also tended to be positively portrayed.

Coverage of people who were of Vietnamese origin or Black was the exception to this rule. All of the stories and photos that referenced the Vietnamese community were produced by Ming Pao staff or obtained by Ming Pao staff from the public. For the Black community, ten out of eleven stories were staff written while twenty of the thirty-four (58\%) photos were either staff generated or obtained from the public.

But this coverage of the Vietnamese community, and, to a lesser extent, the Black community, was dominated by stereotypically negative police and crime-related stories and photos (Figures 3 and 4). The two groups also appeared more frequently than others in stories that contravened the CP standard for when to mention race and ethnicity (Figure 7). That the majority of this coverage originated in the Ming Pao newsroom suggests that the norms, values, training and professional practice of journalists in the newsroom need to be revisited to explore conscious and unconscious biases. 


\section{CONCLUSION}

Ethnic media organizations vary considerably in their size, ownership structures, publication schedules and target audiences. This study of Ming Pao offers insight into the representation of ethnic and racial minorities at a major ethnocultural newspaper that is part of a multinational publishing conglomerate. A similar examination of the practices at smaller publications would round out the picture.

In the meantime, the Ming Pao results suggest there is a need to reach out to journalists working in ethnic media with workshops and training sessions that address issues related to diversity coverage, beginning with an awareness campaign highlighting the Canadian Press standard for the handling of race and ethnicity references, its history and the reasons for its existence. Schools of journalism, ethnic news associations and mainstream journalism organizations are all well placed to take this on.

Research suggests that the journalism practices of reporters and editors working in the ethnic media in North America do sometimes differ from those of mainstream reporters and editors. Ethnic media journalists themselves, for instance, say they often set aside the objectivity that is a central tenet—albeit much contestedof Western journalism in order to assume the role of community leader, activist or organizer (Matsaganis et al. 2011).

Differences in journalism norms are the inevitable result of different cultural, political, and economic forces. But as Levi Obijiofor and Folker Hanusch (2011) observe in their study of journalism cultures, journalism "works best if it is practiced in accordance with local cultural values" (8). In Canada's multicultural context, this means journalists engaged in best practices aspire (admittedly with mixed results) to norms that define useful, accurate, and relevant news as news that reflects community diversity and does not stereotype or vilify members of any racial or ethnic group. Journalists who embrace these norms are better equipped to serve their target audiences and the community as a whole regardless of where they work. Some values, in other words, are not negotiable.

\section{ACKNOWLEDGEMENTS}

This research was generously supported by CERIS—The Ontario Metropolis Centre, the Social Sciences and Humanities Research Council (SSHRC), and Ryerson University. I would like to thank research assistant Christina Wong for her work on data analysis as well as coders Emily Jin, Harbir Natt, Sue Chun and Maria Siassina for their care, diligence and enthusiasm as members of the Local News Research Project (www.localnewsresearchproject.ca) team.

\section{REFERENCES}

Agroskin, Dmitrij, and Eva Jonas. 2010. Out of Control: How and Why does Perceived Lack of Control Lead to Enthocentrism? Review of Psychology 17.2: 79-90.

Ahadi, Daniel, and Catherine A. Murray. 2009. Urban Mediascapes and Multicultural Flows: Assessing 
Vancouver's Communication Infrastructure. Canadian Journal of Communication 34.4: 587-611.

Aulakh, Raveena. 2011. Powerful Punjabi Press has its Fans and Foes. Toronto Star, Nov. 6. http://www.thestar.com/news/article/1082245-powerful-punjabi-press-has-its-fans-and-foes.

Ball-Rokeach, Sandra J., Yong-Chan Kim, and Sorin Matei. 2001. Storytelling Neighborhood: Paths to Belonging in Diverse Urban Environments. Communication Research 28.4: 392-428.

Bun, Chan Kwok. 1990. Hong Kong's Response to the Vietnamese Refugees: A Study in Humanitarianism, Ambivalence and Hostility. Southeast Asian Journal of Social Science 18.1: 94-110.

Chan, Shirley. 2010. The Rise of the Ethnic Media. Canadian Journalism Foundation Panel Presentation, Toronto, Ontario, January 19.

Cheng, Hau Ling. 2005. Constructing a Transnational, Multilocal Sense of Belonging: An Analysis of Ming Pao. Journal of Communication Inquiry 29.2: 141-159.

Cheng, Lucie, and Yen Espiritu. 1989. Korean Businesses in Black and Hispanic Neighbourhoods: A Study of Intergroup Relations. Sociological Perspectives 32.4: 521-534.

Citizens Against Racism and Discrimination. 2007. Racist Article in AsianWeek "Why I Hate Blacks." Feb. 28. http://card.wordpress.com/2007/02/28/racist-article-in-asianweek-why-i-hate-blacks/.

D’Arcy, Stephen. 2007. The “Jamaican Criminal” in Toronto, 1994: A Critical Ontology. Canadian Journal of Communication 32.2: 241-259.

Davis, Howard, and Anna Sosnovskaya. 2009. Representations of Otherness in Russian Newspapers: The Theme of Migration as a Counterpoint to Russian National Identity. Journal of Intercultural Communication 21, October. http://www.immi.se/jicc/index.php/jicc/article/view/44/19.

Diversity Institute. 2010. DiverseCity Counts 2: A Snapshot of Diverse Leadership in the GTA. Toronto: Ryerson University.

DiversiPro. 2007. Research on Settlement Programming Through the Media. Ottawa: Citizenship and Immigration Canada. http://74.125.93.132/custom?q=cache:1jjNfuDogRIJ:atwork.settlement.org/ downloads/atwork/Research_on_Settlement_Programming_Through_the_Media.pdf+research+on + settlement+programming+through+the + media\&cd $=2 \& h l=e n \& c t=c l n k \& c l i e n t=$ google-coop-np.

Fatima, Sahar. 2012. "There is Nothing Called Freedom" for Journalists Working in Ethnic Media. JSource, March 12. http://j-source.ca/article/there-nothing-called-freedom-journalists-working-ethnic-media.

Fleras, Augie. 2009. Theorizing Multicultural Media as Social Capital: Crossing Borders, Constructing Buffers, Creating Bonds, Building Bridges. Canadian Journal of Communication 34.4: 725-729.

. 2011. The Media Gaze: Representations of Diversities in Canada. Vancouver: UBC Press.

Habermas, Jürgen. 1989. The Structural Transformation of the Public Sphere: An Inquiry into a Category of Bourgeois Society. Cambridge: MIT Press.

Henry, Frances. 1999. The Racialization of Crime in Toronto's Print Media: A Research Project. Toronto: School of Journalism, Ryerson Polytechnic University.

Henry, Frances, and Carol Tator. 2002. Discourses of Domination: Racial Bias in the Canadian EnglishLanguage Press. Toronto: University of Toronto Press.

Hunt, Peter Geoffrey. 1996. Dragons and Chicken Wings: The Anomalies of the Involvement of Vietnamese Refugees in Crime in Hong Kong, 1989-1995. M.A. thesis, University of Hong Kong.

Husband, Charles. 2005. Minority Ethnic Media Communities as Communities of Practice: Professionalism and Identity Politics in Interaction. Journal of Ethnic and Migration Studies 31.3: 461-479.

Huston, Gabriel. 2012. Canada's Ethnic Media: A Socioeconomic National Report on Canada's CommunityBased Ethnic/Third-Language Media. Toronto: National Ethnic Press and Media Council of Canada.

Ibroscheva, Elza, and Jyotika Ramaprasad. 2008. Do Media Matter? A Social Construction Model for Stereotypes of Foreigners. Journal of Intercultural Communication 34, April. http://immi.se/intercultural/nr16/ibroscheva.htm.

Ipsos Reid. 2007. Canadian Chinese Media Monitor. Ipsos Reid. http://docs.google.com/viewer?a=v\&q= cache:DrGKL0Od6XIJ:news.singtao.ca/singtaomedia/2007suvey.pdf+2007+Canadian+Chinese+Me dia+Monitor\&hl=en\&gl=ca\&pid=bl\&srcid=ADGEESiFo5OyLf2AInOc-E0Br5vSylJzJea8jxIT KmU5AOhAKlwQq5442Y37mkFAS0YiAL_24MSqA-9PsjTb3vM8IaKIoDRJ7tL0JGGhcgf_ ti0Ggspk7tw2hFUsZ4Qul7mcj9GsWR0Z\&sig=AHIEtbTnPOGHEOajNytw2RZQ72nsd4McYA. 
Jiwani, Yasmin. 2006. Discourses of Denial: Mediations of Race, Gender and Violence. Vancouver: UBC Press.

Kaniss, Phyllis. 1991. Making Local News. Chicago: University of Chicago Press.

Karim, Karim H. 2002. Public Sphere and Public Sphericules: Civic Discourse in Ethnic Media. In Civic Discourse and Cultural Politics in Canada, ed. S. Devereaux Ferguson and L. Regan Shade, 230-242. Westport, CT: Ablex.

Lam, Tak Yin. 2010. Interview with Ming Pao deputy editor in chief, May 3.

Lin, Wan-Ying, and Hayeon Song. 2006. Geo-Ethnic Storytelling. Journalism 7.3: 362-388.

Lin, Wan-Ying, Hayeon Song, and Sandra Ball-Rokeach. 2010. Localizing the Global: Exploring the Transnational Ties that Bind in New Immigrant Communities. Journal of Communication 60.2: 205-229.

Lindgren, April. 2011. Interpreting the City: Portrayals of Place in a Toronto-Area Ethnic Newspaper. Aether: The Journal of Media Geography 8A: 68-88.

Lippmann, Walter. 1997. Public Opinion. New York, NY: Simon and Schuster. (First published in 1922).

Liu, Liangni. 2009. The Representation of Maori in Local Chinese Language News Media in New Zealand. Journal of Intercultural Studies 30.4: 403-429.

Lombard, Matthew, Jennifer Snyder-Duch, and Cheryl Campanella Bracken. 2002. Content Analysis in Mass Communication: Assessment and Reporting of Intercoder Reliability. Human Communication Research 28.4: 587-604.

Matsaganis, Matthew D., Vikki S. Katz, and Sandra J. Ball-Rokeach. 2011. Understanding Ethnic Media: Producers, Consumers and Societies. Thousand Oaks, CA: Sage.

Mahtani, Minelle. 2001. Representing Minorities: Canadian Media and Minority Identities. Canadian Ethnic Studies 33.3: 99-131.

- 2008. How Are Immigrants Seen—and What Do They Want to See? Contemporary Research on the Presentation of Immigrants in the Canadian English-Language Media. In Immigration and Integration in Canada in the Twenty-first Century, ed. John Biles, Meyer Burstein and James Frideres, 231-251. Kingston, ON: Queen's University.

Miller, John. 2006. Canada's Ethnocultural Press: Survey of Publishers, 2006. Ottawa: Heritage Canada.

Ming Pao. 2008a. Two Robberies in Scarborough, Jan. 9.

- 2008b. Male Attacked While Inside Car, Bullet Shot to the Chest, March 21.

2008c. Science Fair, April 6.

2008d. Sponsored by a Number of Large Organizations, Caribana Parade Will Be Held, April 22.

2008e. Vietnamese Man Charged, Involved in Three Marijuana Grow-Ops in Markham, May 8.

2008f. Tragedy Strikes Brampton: Mentally Ill Man Harms Own Child with Knife, May 16.

2008g. Workers Suspicious of Car Factory Shutdown: Demand Changes to the Labour Laws, Companies Must Compensate Workers First in Case of Bankruptcy, July 11.

Ming Pao Daily News. 2012. About Us. http://translate.google.com/translate?hl=en\&prev=/search\% 3Fq\%3Dming\%2Bpao\%2Btoronto\%26hl\%3Den\%26biw\%3D1920\%26bih\%3D875\%26prmd\%3Di mvnso\&rurl=translate.google.ca\&sl=zh-TW\&u=http://www.mingpaotor.com/cfm/intro_Eng.cfm.

Murray, Catherine. 2008. Media Infrastructure for Multicultural Diversity. Policy Options 29.4: 63-66.

Murray, Catherine, Sherry Yu and Daniel Ahadi. 2007. Cultural Diversity and Ethnic Media in British Columbia. A Report to Department of Canadian Heritage, Western Region (Study No. 451933670). Centre for Policy Studies on Culture and Communities, Simon Fraser University. http://www.bcethnicmedia.ca/research.html.

New America Media. 2007. Deep Divisions, Shared Destiny: A Poll of African Americans, Hispanics and Asian Americans on Race Relations Sponsored by New America Media and Nine Founding Ethnic Media Partners. http://news.newamericamedia.org/news/view_article.html?article_id=28501933d0e5c5 $344 \mathrm{~b} 21 \mathrm{f} 9640 \mathrm{dc} 13754$.

Obijiofor, Levi, and Folker Hanusch. 2011. Journalism Across Cultures: An Introduction. New York: Palgrave Macmillan.

Paek, Hye-Jin, So-Hyang Yoon and Dhavan V. Shah. 2005. Local News, Social Integration, and Community Participation: Hierarchical Linear Modeling of Contextual and Cross-Level Effects. Journalism and Mass Communication Quarterly 82.3: 587-606.

Park, Robert E. 1923. The Natural History of the Newspaper. American Journal of Sociology 29.3: 273-289. 
Putnam, Robert. 2007. E Pluribus Unum: Diversity and Community in the Twenty-First Century. Scandinavian Political Studies 30.2: 137-174.

Pyke, Karen, and Tran Dang. 2003. "FOB" and "Whitewashed": Identity and Internalized Racism Among Second Generation Asian Americans. Qualitative Sociology 26.2: 147-172.

Roy, Sandip. 2007. New Poll Highlights Media's Role in Covering Race Relations. http://news.newamericamedia.org/news/view_article.html?article_id=fd84dc7214fada3cabca809de9889c24.

Solutions Research Group. 2006. Study Explores Media Use Among Growing Ethnic Groups. http:// www.srgnet.com/diversity/index.html.

Special Committee on Participation of Visible Minorities in Canadian Society. 1984. Equality Now: Report of the Special Committee on Visible Minorities in Canadian Society, Report 91-109. Ottawa: Supply and Services Canada.

Statistics Canada. 2006a. Canada's Ethnocultural Mosaic, 2006 Census: Canada's Major Census Metropolitan Areas. Ottawa: Statistics Canada. http://www12.statcan.ca/english/census06/analysis/ ethnicorigin/toronto.cfm.

- 2006b. Detailed Mother Tongue, Knowledge of Official Languages, Age Groups and Sex for the Population of Canada, 2006 Census. Catalogue \# 97-555-XWE2006015. Ottawa: Statistics Canada.

- 2008. Community Profiles: Toronto Census Metropolitan Area. http://www12.statcan.ca/censusrecensement/2006/dp-pd/prof/92-591/details/page.cfm?Lang=E\&Geo1=CMA\&Code1=535\&Geo2= $\mathrm{PR} \&$ Code $2=35 \&$ Data $=$ Count $\&$ SearchText $=$ toronto $\&$ Search Type $=$ Begins $\&$ SearchPR $=01 \& B 1=A l l \& C$ ustom $=$.

- 2010. Projections of the Diversity of the Canadian Population, 2006 to 2031. Statistics Canada Catalogue no. 91-551-X. http://www.statcan.gc.ca/daily-quotidien/100309/dq100309a-eng.htm

Tasko, Patti, ed. 2006. The Canadian Press Stylebook: A Guide for Writing and Editing. Toronto: Canadian Press.

Taylor, Bob, ed. 1983. The Canadian Press Stylebook: A Guide for Writing and Editing. Toronto: Canadian Press.

Tereskinas, Arturas. 2003. Toward a New Politics of Citizenship: Representation of Ethnic and Sexual Minorities in Lithuanian Mass Media. Budapest: Central European University Centre for Policy Studies. http://pdc.ceu.hu/contact.html.

Yip, Joyce. 2010. State of Disarray. Ryerson Review of Journalism, Summer: 67-70.

APRIL LINDGREN is Associate Professor at Ryerson University's School of Journalism, and director of the Ryerson Journalism Research Centre. She is the principal investigator for the Local News Research Project (www.localnewsresearchproject.ca). 